\title{
EVALUATION OF THE ROLE OF VIRUSES IN CAUSING PERI-IMPLANTITIS- A PCR STUDY IN A CASE SERIES
}

\author{
Shivaprasad Bilichodmath1, Ramesh Chowdhary2, Sruthi K. Nair ${ }^{3}$, Rekha Bilichodmath4, Ume Sameera 5
}

${ }_{1}^{1}$ Professor, Department of Periodontology, Rajarajeswari Dental College and Hospital.

${ }_{2}^{2}$ Professor, Department of Prosthodontics, Rajarajeswari Dental College and Hospital.

${ }^{3}$ Postgraduate Student, Department of Periodontology, Rajarajeswari Dental College and Hospital.

${ }^{4}$ Postgraduate Student, Department of Periodontology, Rajarajeswari Dental College and Hospital.

5 Postgraduate Student, ${ }^{5}$ Department of Periodontology, Rajarajeswari Dental College and Hospital.

\section{PRESENTATION OF CASE}

A total of 3 male patients without any contributory medical history were selected for the present case series aged 23,44 and 47 years. Granulation tissue was procured using sterile curette around failed implants. Patient 2 was a known smoker since 2 years and was explained about the risk of smoking and implant survival. Immediate loading of implant was performed in patient 1 at 31 regions. In patient 2 and 3, implants were conventionally loaded after 6 months of implant placement at 16 and 24 regions respectively. The implants failed at 9 months, 12 months and 14 months in patient 1,2 and 3 respectively after loading the implants.
\end{abstract}

HOW TO CITE THIS ARTICLE Bilichodmath S, Chowdhary R, Nair SK, et al. Evaluation of the role of viruses in causing for periimplantitis- a PCR study in a case series. J. Evolution Med. Dent. Sci. 2018;7(07):932-934, DOI: 10.14260/jemds/2018/212

\section{DIFFERENTIAL DIAGNOSIS}

Peri-implant mucositis and chronic periodontitis were considered.

\section{CLINICAL DIAGNOSIS}

Peri-implantitis.

\section{PATHOLOGICAL DISCUSSION}

Periodontitis is an inflammatory process that occurs around the surrounding tissues of the teeth, which is caused by group of microorganisms and results in progressive destruction of periodontal ligament and alveolar bone. ${ }^{1}$ Bacteria-induced inflammatory responses are involved in periodontal tissue harm, and the severity of periodontitis is reliant on the dynamic equilibrium of communications between the microbial challenge and the host immune inflammatory response. ${ }^{1}$

Bacterial aetiology alone has not been able to substantiate various aspects of periodontal pathogenesis such as i) Rapid periodontal tissue breakdown with minimal plaque, ${ }^{2}$ ii) Phases of disease activity and quiescence, ${ }^{3}$ iii) Site specificity in periodontal diseases ${ }^{4}$ and iv) Progression to advanced periodontal destruction, which occurs in fraction of given population. ${ }^{5}$ Peri-implantitis is defined as an inflammatory reaction affecting the tissues surrounding osseo-integrated dental implants,

'Financial or Other Competing Interest': None.

Submission 02-01-2017, Peer Review 26-01-2018,

Acceptance 01-02-2018, Published 12-02-2018.

Corresponding Author:

Dr. Shivaprasad Bilichodmath,

Professor, Department of Periodontology,

Rajarajeswari Dental College and Hospital.

\#14, Ramohalli Cross, Kumbalgodu, Mysore Road,

Bangalore-560074, Karnataka, India.

E-mail: drshivaprasad2008@yahoo.co.in

DOI: $10.14260 /$ jemds $/ 2018 / 212$ thereby resulting in the loss of supporting bone. ${ }^{6}$ Infections of the implant bearing soft and hard tissues initiate periimplantitis, which shares a similar bacterial flora with periodontitis. The key pathogens associated with periodontal disease are the Gram-negative, black-pigmented anaerobic flora. ${ }^{7}$ Studies have revealed that the bacterial flora at failing implant sites consists of Gram-negative rods including Bacteroides and Fusobacterium spp. ${ }^{7}$

Literature has shown the prevalence of herpes viruses like herpes simplex virus (HSV-1 and 2), Epstein-Barr virus (EBV), Human Cytomegalovirus (HCMV) in periodontal pockets and gingival tissue of periodontitis patients suggesting a role in the pathogenesis of periodontitis.[8,9]

The soft and hard tissues that surround osseointegrated (bone-to-implant contact) implants show some similarities with natural periodontium, a periodontitis-like process and peri-implantitis. This can affect dental implants. ${ }^{10}$ Since untreated periodontitis may ultimately lead to the loss of natural teeth, similarly peri-implantitis can also result in the failure of dental implants. ${ }^{10}$ As peri-implant tissue is similar to periodontal tissue, herpes viral bacterial synergism might as proven in periodontal pathogenesis.

HCMV and EBV infected inflammatory cells produce tissue-destroying cytokines and these may impair the ability to defend against periodonto-pathogen bacterial challenge.[1114] If herpes viruses have the biological mechanisms to encourage periodontal tissue destruction, then the role and influence of herpes viruses in periimplantitis should be carefully evaluated. Recently, a study confirmed the high prevalence of HCMV and EBV in subgingival plaque of periimplantitis sites and suggested a possible active pathogenic role of the viruses in periimplantitis. ${ }^{15}$

Literature does not show any evidence on presence of herpes virus as the microorganism in causing periimplantitis, further leading to the cause of implant failure.

Hence, this study was carried out to evaluate the presence of herpes virus like HCMV, EBV and HSV-1 at the implant failed sites. DNA was extracted using PureLink ${ }^{\circledR}$ Genomic DNA kits from Life Technologies, Bangalore which allow rapid and efficient purification of genomic DNA. The granulation tissue around the failed implant was transferred to a new Eppendorf tube and $180 \mu \mathrm{L}$ of pure link Genomic buffer and $20 \%$ proteinase buffer was added. It was ensured that tissue was completely immersed in the buffer mix. The tubes were kept at $55^{\circ} \mathrm{C}$ for 2 hours in water bath with occasion vortexing unless and until it is completed. $20 \mu \mathrm{L}$ of RNAse-A was added to the lysate and mixed well by briefly vortexing play a possible role in peri-implantitis (PI) aetiopathogenesis 
and was incubated at room temperature for 2 minutes. 200 $\mu \mathrm{L}$ of PureLink ${ }^{\mathrm{TM}}$ Genomic Lysis/ Binding buffer was added and mixed well by vortexing to obtain a homogeneous solution. $200 \mu \mathrm{L}$ of $96 \%-100 \%$ ethanol was then added and mixed well by vortexing for 5 seconds to obtain a homogeneous solution and was subjected to purification protocol according to manufacturer's instructions.

\section{Primers and Probes}

Custom TaqMan® inventoried assay for pathogen identification were used to identify HCMV and EBV. Assay ID for HCMV was Pa03453400_s1, the gene symbol was UL132 and the catalogue number was 4331182 . Assay ID for EBV is Pa03453399_s1, the gene symbol was IR1 and the catalogue number was 4331182 . The assay was designed to a sequence that does not exhibit typical exon-intron-exon gene structure, such as fusion transcript or artificial, prokaryotic or mitochondrial sequences. As the assay procured from Applied Biosystems/ Life technologies was inventoried, the individual HCMV and EBV primer and probe sequences were not provided or disclosed by the manufacturer.

The Sequences of HSV-1 Primers and Probes were as follows-

- HSV-1

- Forward primer: GCG CGT GTA CCA CAT CCA

- Reverse primer: TCC AAC ACG GCG TAG TAA ACC

- Probe: 6FAM-ACC GGA CCC GTT CCA G

\section{PCR Procedure}

Reagents from Life Technologies ${ }^{\mathrm{TM}}$ and Real-Time PCR Systems from Applied Biosystem ${ }^{\mathrm{TM}}$ were used in this study. Custom TaqMan pathogen identification assay for HCMV, EBV and HSV-1 was used in this study. TaqMan Polymerase Reaction was performed with a final volume of $20 \mu \mathrm{L}$ Polymerase Chain Reaction mixture. (Fig. 1) The condition for real time polymerase chain reaction was as follows: Preheating at $50^{\circ} \mathrm{C}$ for 2 minutes and at $95^{\circ} \mathrm{C}$ for 10 minutes followed by 40 cycles of shuttle heating at $95^{\circ} \mathrm{C}$ for 15 seconds and at $60^{\circ} \mathrm{C}$ for 1 minute. 16s RNA was used as the endogenous control (TaqMan pre-developed assay reagents Applied Biosystems - India). The comparative threshold cycle or $\mathrm{C}_{\mathrm{t}}$ method was used to assess the amplified transcripts.

\section{RESULTS}

Herpes viruses were detected in all the samples of granulation tissue around failed implants. (Fig.1) The tissue samples were positive for HCMV, EBV and HSV-1. The PCR amplification plots were as depicted in Fig. 2, 3 and 4.

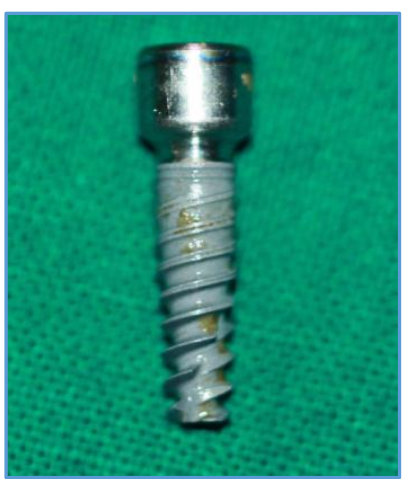

Figure-1

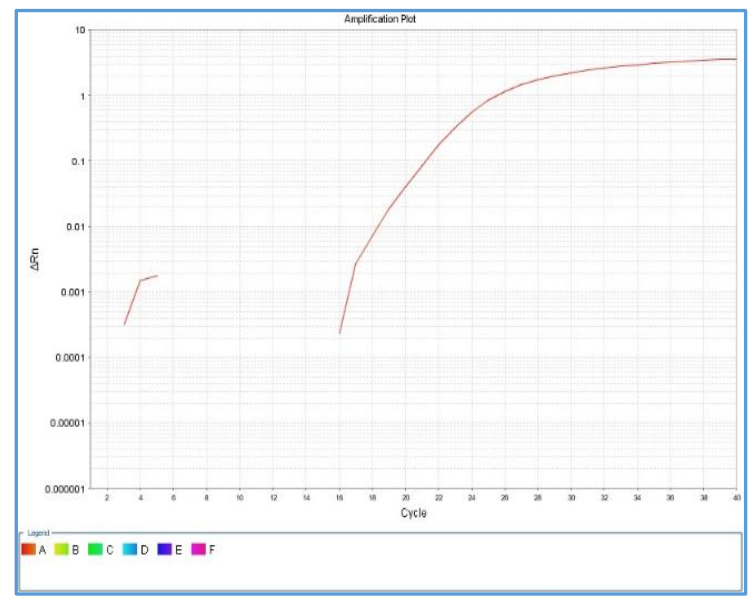

Figure 2 Amplification Plot for HCMV

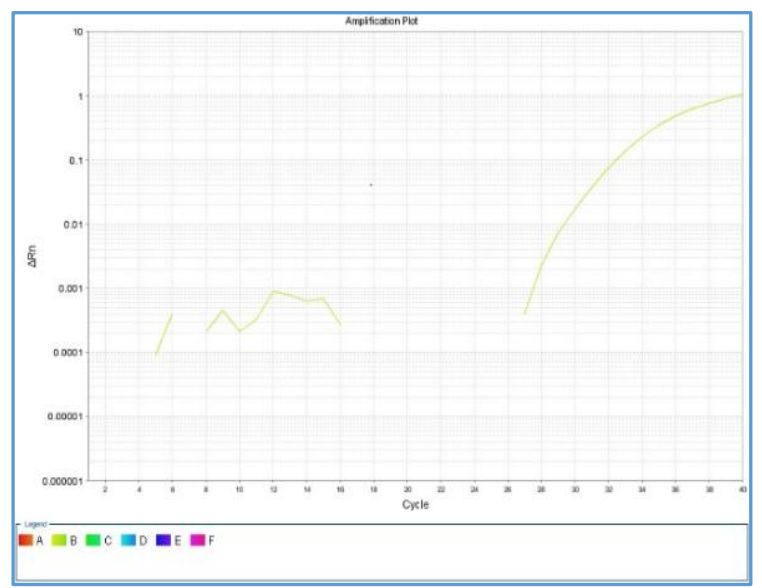

Figure 3 Amplification Plot for HSV1

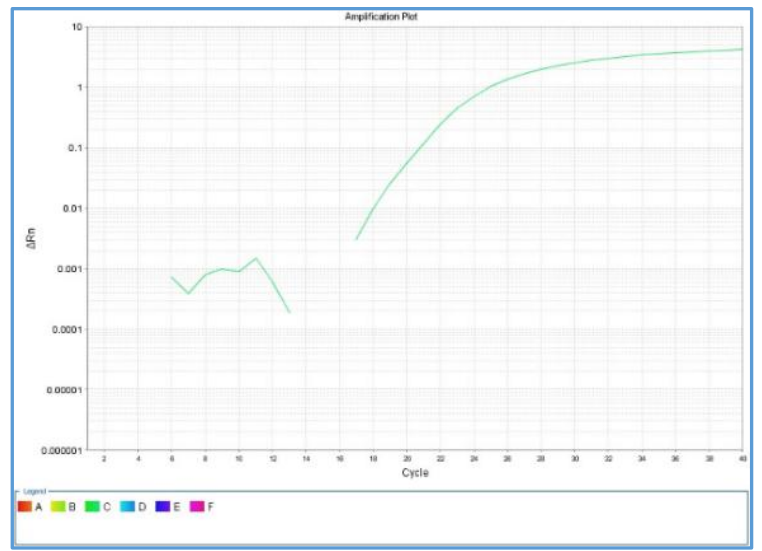

Figure 4 PCR Amplication Plot for EBV

\section{DISCUSSION OF MANAGEMENT}

Considering the fact that the causal pattern of peri-implantitis is still incomplete, the present case series describes the prevalence of herpes viruses like Human cytomegalovirus (HCMV), Epstein-Barr virus (EBV) and Herpes simplex virus1 (HSV-1) in the granulation tissue around failed implants. Granulation tissue was procured from 3 systemically healthy patients aged 23, 44 and 47 years. Reagents from Life Technologies $^{\mathrm{TM}}$ and Real-time PCR Systems from Applied Biosystems $^{\mathrm{TM}}$ were used in this study and TaqMan Polymerase Reaction was performed with a final volume of $20 \mu \mathrm{L}$ Polymerase Chain Reaction mixture. 
Studies beyond doubt have proved that herpes viruses are involved in pathogenesis of periodontitis. The subgingival presence of both EBV and HCMV was reported to be associated with the major periodontopathic bacteria and the severity of periodontal disease. 15 Thus, findings suggest that periodontitis occurs more frequently and progresses more rapidly in sites infected by EBV and HCMV rather than in noninfected sites.

Studies by Contreras et al and Shivaprasad et al have shown the prevalence of herpes viruses like herpes simplex virus (HSV 1 and 2), Epstein-Barr virus (EBV), human cytomegalovirus (HCMV) in the periodontal pockets, ${ }^{8}$ gingival tissue $^{8}$ and plaque ${ }^{9}$ of periodontitis patients. These findings suggest a strong association between the presence of these viruses and measurement of probing depth, clinical attachment loss and the severity of the disease.

Peri-implantitis may have a multifactorial background, where an aberrant host response together with bacterial challenge may result in development of tissue destruction around the implants. ${ }^{16}$ Since bacteria were recognised to be the main causative factor of periodontal disease, the role of microorganisms in the development and progression of periimplantitis became the focus of several lines of research. As peri-implant tissue is similar to periodontal tissue, herpes viral bacterial synergism might play a potential role in periimplantitis (PI) aetiopathogenesis.

The mechanism of Herpes virus in disease causing and progression are explained under the following Points by

\section{Slots 13 ? Immune}

invasion.

- Immunopathogenecity.

- Tissue Tropism

- Cytopathic Effect.

- Reactivation from Latency.

Few studies have proven that herpes viruses are more prevalent in peri-implantitis than compared to healthy implants. Recently, a pilot study by Jankovic et al evaluated the prevalence of HCMV and EBV DNA in the subgingival plaque of peri-implantitis sites, which suggests that herpes viruses have a possible active pathogenic role in periimplantitis. 15 Another study by the same author was conducted to estimate the prevalence of different genotypes of human cytomegalovirus (HCMV) and Epstein-Barr virus (EBV) in peri-implantitis and mucositis sites and to evaluate the correlation between herpes virus presence and clinical parameters. The results from the study confirmed the high prevalence of HCMV-2 and EBV-1 in peri-implant tissue plaque of peri-implantitis sites and suggests a possible active pathogenic role of viruses in peri-implantitis. ${ }^{17}$ Further, randomised control trials with larger sample size should be conducted to better understand the precise role of herpes viruses in the pathogenesis of peri-implantitis. This knowledge will be useful in preventing and treating periimplantitis. With these findings we hypothesise that herpes viruses might have a significant role in pathogenesis of periimplantitis.

FINAL DIAGNOSIS Peri-implantitis.

\section{REFERENCES}

[1] Loesche WJ, Grossman NS. Periodontal disease as a specific albeit chronic infection: diagnosis and treatment. Clin Microbiol Rev 2001;14(4):727-52.

[2] Lang N, Bartold PM, Cullinan M, et al. Consensus report: aggressive periodontitis. Ann Periodontol 1999;4(1):53.

[3] Goodson J, Tanner AC, Haffajee AD, et al. Patterns of progression and regression of advanced destructive periodontal disease. J Clin Periodontol 1982;9(6):47281.

[4] Lindhe J, Ranney R, Lamster I. Consensus report: chronic periodontitis. Ann Periodontol 1999;4(1):38

[5] Papapanou PN. Periodontal diseases: epidemiology. Ann Periodontol 1996;1(1):1-36.

[6] Albrektsson T, Isidor F. Consensus report of Session IV. In: Lang NP, Karring T, eds. Proceedings on the 1st European workshop on periodontology. $1^{\text {st }}$ edn. Germany: Quintessence Publishing 1994;365-9.

[7] Mombelli A, van Oosten MA, Schurch E, et al. The microbiota associated with successful or failing osseointegrated titanium implants. Oral Microbiol Immunol 1987;2(4):145-51.

[8] Contreras A, Nowzari H, Slots J. Herpesviruses in periodontal pocket and gingival tissue specimens. Oral Microbiol Immunol 2000;15(1):15-8.

[9] Bilichodmath S, Mangalekar SB, Sharma DC, et al. Herpesviruses in chronic and aggressive periodontitis patients in an Indian population. J Oral Sci 2009;51(1):79-86.

[10] Meffert RM. Periodontitis vs. peri-implantitis: the same disease? The same treatment? Crit Rev Oral Bio Med 1996;7(3):278-91.

[11] Slots J. Herpesviruses in periodontal diseases. Periodontol 2000 2005;38:33-62.

[12] Contreras A, Umeda M, Chen C, et al. Relationship between herpesviruses and adult periodontitis and periodontopathic bacteria. J Periodontol 1999;70(5):478-84.

[13] Slots J, Kamma JJ, Sugar C. The herpesvirusporphyromonas gingivalis-periodontitis axis. J Periodontal Res 2003;38(3):318-23.

[14] Slots J, Schonfeld SE. Actinobacillus actinomycetemcomitans in localized juvenile periodontitis. In: Hamada S, Holt SC, McGhee RJ, eds. Periodontal disease: pathogens and host immune responses. Tokyo: Quintessence Publishing Co 1991:53-64.

[15] Jankovic S, Aleksic Z, Dimitrijevic B, et al. Prevalence of human cytomegalovirus and Epstein-Barr virus in subgingival plaque at peri-implantitis, mucositis and healthy sites. A pilot study. Int J Oral Maxillofac Surg 2011;40(3):271-6.

[16] Hultin M, Gustafsson A, Hallström H, et al. Microbiological findings and host response in patients with peri-implantitis. Clin Oral Implants Res 2002;13(4):349-58.

[17] Jankovic S, Aleksic Z, Dimitrijevic B, et al. Correlation between different genotypes of human cytomegalovirus and Epstein-Barr virus and periimplant tissue status. Aust Dent J 2011;56(4):3828. 